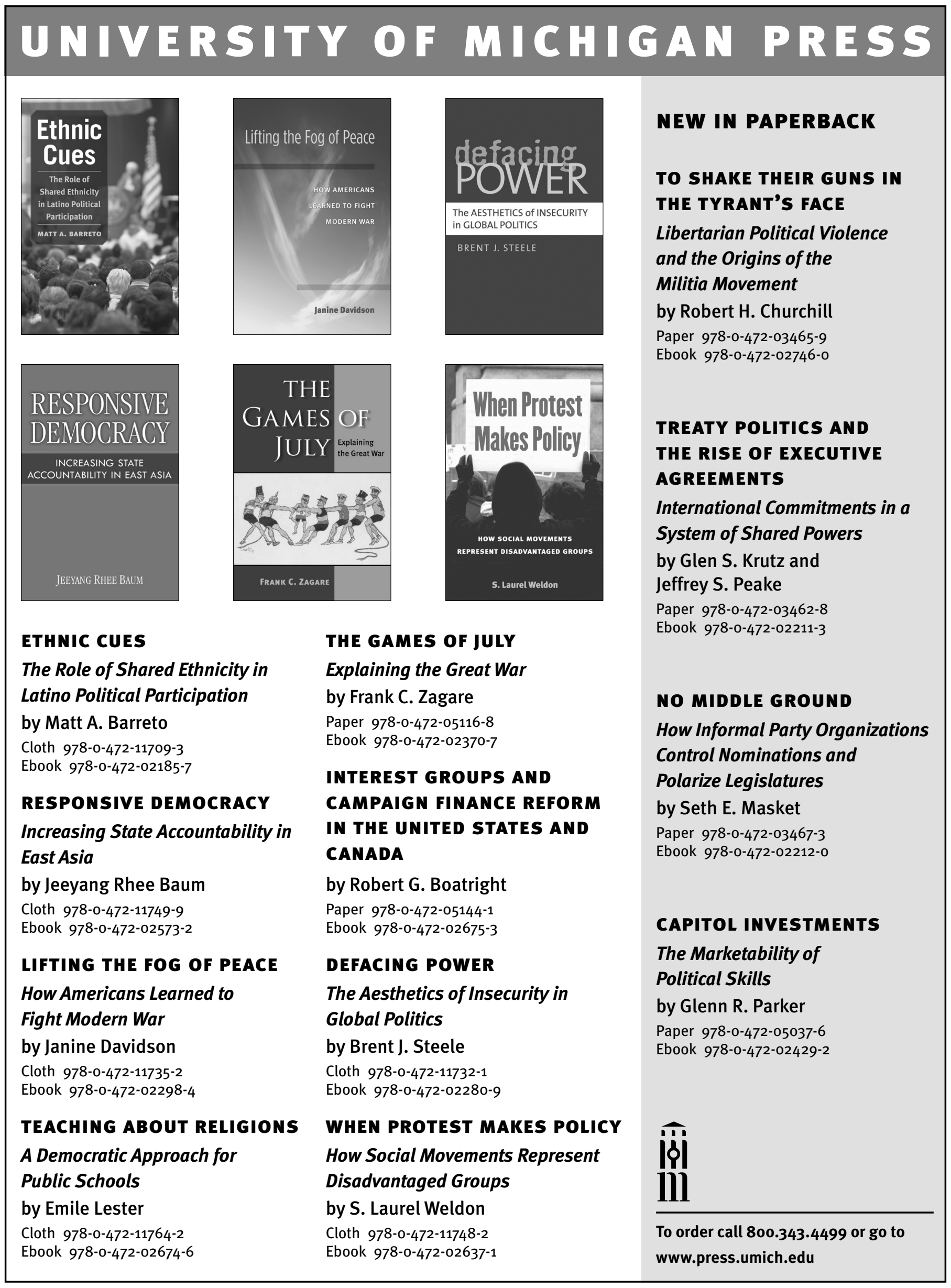




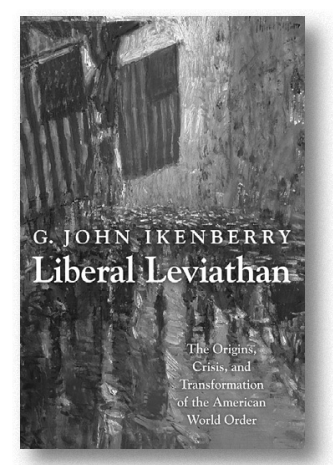

\section{Liberal Leviathan}

The Origins, Crisis, and

Transformation of the American

World Order

\section{G. John Ikenberry}

"Tough-minded yet visionary and optimistic, this inspirational volume should become required reading for all those tasked with the great responsibility of steering us to safety through the very choppy international waters into which we are now heading."

-Michael Cox, London School of

Economics and Political Science

Cloth \$35.00 978-0-691-12558-9

\section{Theories of International} Politics and Zombies

Theories of

INTERNATIONAL POLITICS AND TUNBIES

Daniel W. Drezner
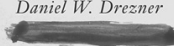

\section{Daniel W. Drezner}

"Bless Dan Drezner for this book which punches huge holes in the hokum of American foreign policy thinking. Our theories in this business have been thin and often very costly, and if it takes Drezner's 'zombie attack' to puncture their bloat, so be it. Besides, the book is fun."

-Leslie H. Gelb, president emeritus of the Council on Foreign Relations and former New York Times columnist

Paper with French folds $\$ 14.95$ 978-0-691-14783-3
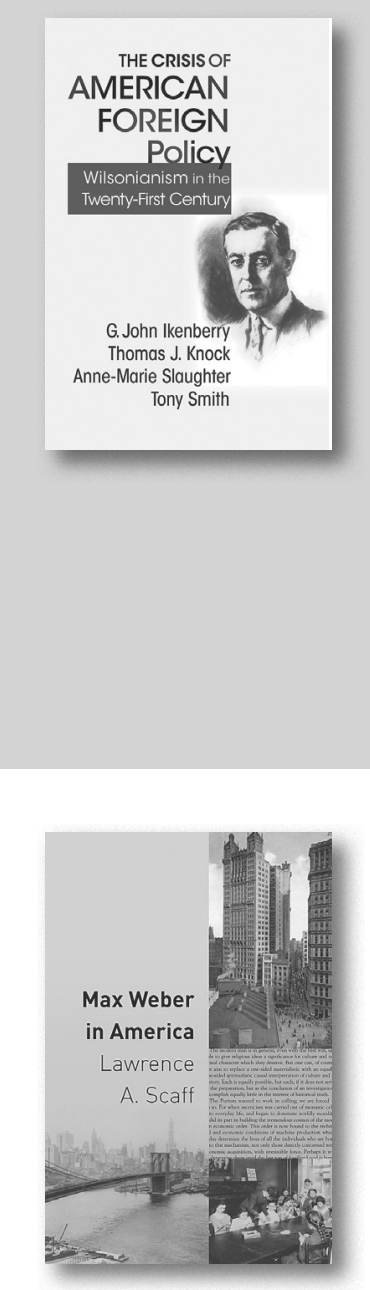

\section{The Crisis of American} Foreign Policy

Wilsonianism in the Twenty-first Century

G. John Ikenberry, Thomas J. Knock, Anne-Marie Slaughter \& Tony Smith

"[A] provocative and informative analysis of the impact of Woodrow Wilson's global vision on American foreign policy over the past century and its potential implications for the twenty-first century. ... This volume should serve as an important resource for foreign policy students and analysts."

-James M. McCormick, Perspectives on Politics

Paper \$17.95 978-0-691-15004-8

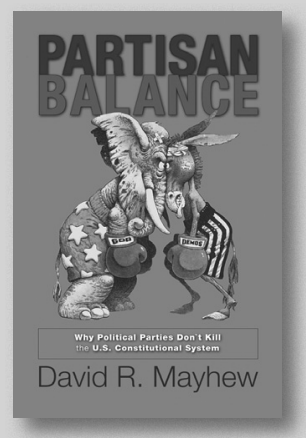

\section{Partisan Balance}

Why Political Parties Don't Kill the U.S. Constitutional System

David R. Mayhew

"Gridlock? Polarization? A constitution undermined by political parties and special interests? Think again. David Mayhew's eye-opening Partisan Balance explains how the political parties have in fact been integral to the survival of the U.S. Constitution and the instrument of American democracy, rather than its undoing."

-Stephen Ansolabehere,

Harvard University

Cloth \$27.95 978-0-691-14465-8

\section{Max Weber in America}

Lawrence A. Scaff

"Max Weber in America is a masterpiece. Scaff is recognized as a leading Weber scholar and social theorist, and here he demonstrates the intellectual significance of Weber's visit to the United States both for Weber's work and for its subsequent American reception. There is no comparable book."

—Guenther Roth, professor emeritus, Columbia University

Cloth \$35.00 978-0-691-14779-6

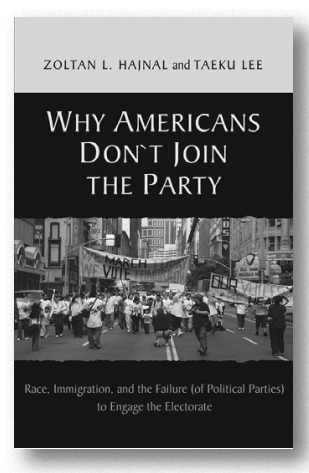

\section{Why Americans Don't Join the Party}

Race, Immigration, and the Failure (of Political Parties) to Engage the Electorate Zoltan L. Hajnal \& Taeku Lee

"This remarkable and engaging book is a thorough investigation of contemporary partisanship and makes a strong contribution to the field of American politics. No other book theorizes the mechanisms that drive party identification in black, Latino, and Asian American communities."

—Janelle Wong, University of Southern California

Paper \$27.95 978-0-691-14879-3 Cloth \$75.00 978-0-691-14878-6 

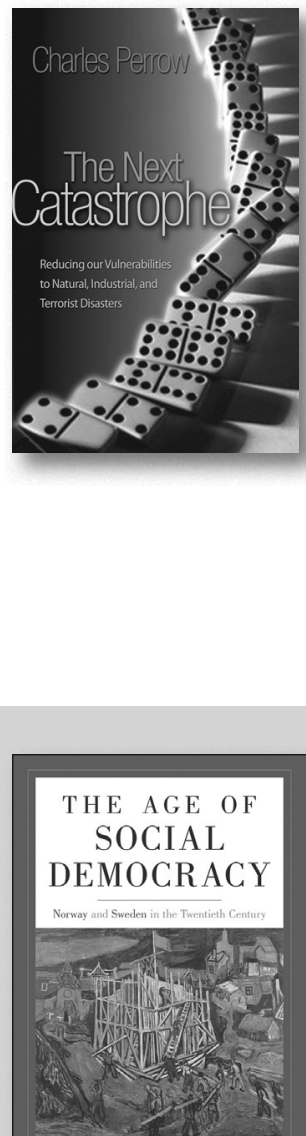

FRANCIS SEJERSTED

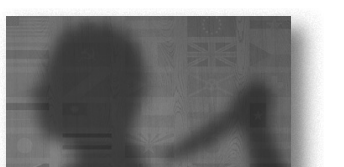

The New LOBAL RULERS

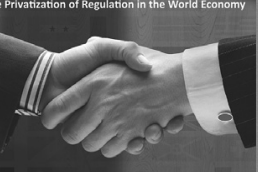

Tim Büthe \& Watter Mattil

\section{The Next Catastrophe}

Reducing Our Vulnerabilities to Natural, Industrial, and

Terrorist Disasters

\section{Charles Perrow}

With a new preface by the author

“[Perrow's] 1984 book Normal Accidents and his many publications systems are vulnerable to disaster have achieved iconic status. In The Next Catastrophe, Perrow extends his analysis to incorporate 'natural' disasters and terrorism more fully." -American Prospect

Paper \$19.95 978-0-691-15016-1

\section{The Age of}

\section{Social Democracy}

Norway and Sweden in the Twentieth Century

Francis Sejersted

Translated by Richard Daly with editing by Madeleine B. Adams

"It is very rare to find this kind of grand historical work today, a synthetic account of a major political movement that spans more than a hundred years and covers two countries. Sejersted demonstrates an almost phenomenal knowledge of the research."

-Bo Rothstein, University of Gothenburg

Cloth \$39.95 978-0-691-14774-1 analyzing how and why technological

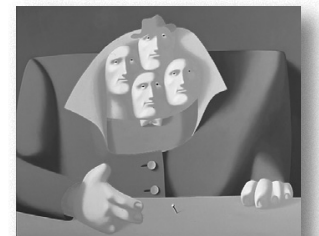

Mafias on the Move

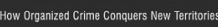

xamentingers

FEDERICO VARESE

\section{Mafias on the Move}

How Organized Crime Conquers New Territories

Federico Varese

"Federico Varese is two writers rolled into one: a fearless fact-hunter who goes after his quarry with the zeal of a thoroughbred journalist, and a dedicated academic who examines and analyzes his catch with relentless detachment. Throw in a robust understanding of the impact of contemporary history on the behavior of a globalized criminal underworld and you have both a compelling read and an impeccable work of reference."

—John le Carré

Cloth $\$ 35.00$ 978-0-691-12855-9

\section{The New Global Rulers}

The Privatization of Regulation in the World Economy

Tim Büthe \& Walter Mattli

"When you buy an electrical appliance or rely on corporate accounts, you are affected by transnational private regulation-a technical arena that is also highly political. In The New Global Rulers, Tim Büthe and Walter Mattli brilliantly explain who wins, and who governs, in this significant but understudied domain."

—Robert O. Keohane,

Princeton University

Cloth \$27.95 978-0-691-14479-5

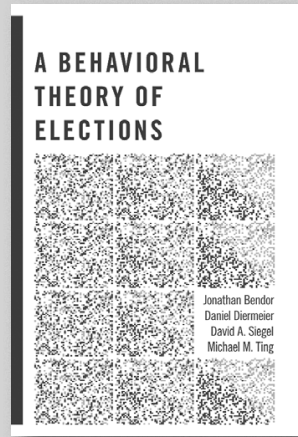

\section{A Behavioral Theory of Elections}

Jonathan Bendor, Daniel Diermeier, David A. Siegel \& Michael M. Ting

"Traditional approaches in political science and economics have failed to explain why people vote or take other actions that apparently have no basis in self-interest. In this pathbreaking book, the authors provide the analytical foundations for a new behavioral theory of political participation." -Stephen Ansolabehere, Harvard University

Paper \$29.95 978-0-691-13507-6 Cloth $\$ 70.00$ 978-0-691-13506-9

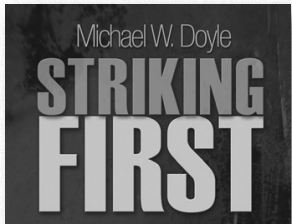

Preemption and Prevention in International Conflict

\section{Striking First}

Preemption and Prevention in International Conflict Michael W. Doyle

Edited and introduced by Stephen Macedo

"This is an extraordinarily useful framework for evaluating preventive action in a complex world involving difficult choices. ... [Striking First] is an indispensable book for those interested in the question of the justifiability of preventive action against future threats. Given the omnipresence of those threats, that should include all of us."

-Jack S. Levy, Perspectives on Politics

Paper \$17.95 978-0-691-14996-7 


\section{WHAT'S NEW IN POLITICAL SCIENCE?}
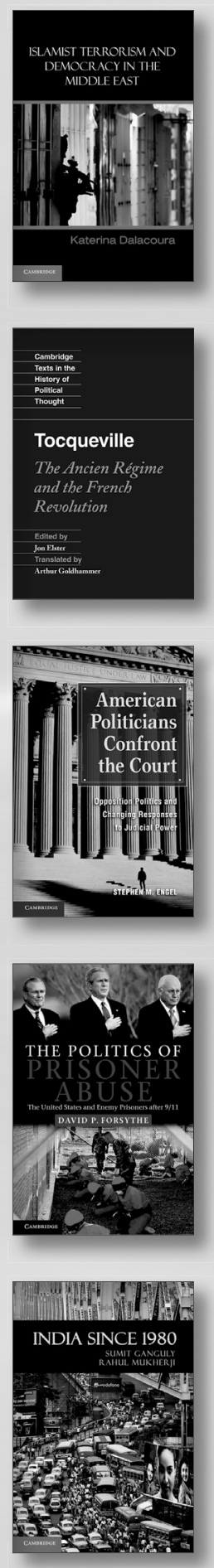

The Future of

Representative

Democracy

Edited by Sonia Alonso, JOHN KEANE, and Wolfgang Merkel \$90.00: $\mathrm{Hb}: 978-1-107-00356-9$ \$32.99: Pb: 978-0-521-17703-0: $322 \mathrm{pp}$.

Battling Pornography

The American Feminist Anti-Pornography Movement, 1976-1986

Carolyn Bronstein

\$85.00: Hb: 978-0-521-87992-7 \$25.99: Pb: 978-1-107-40039-9: $376 \mathrm{pp}$.

The Cambridge Companion to Gandhi Edited by Judith BRown and Anthony Parel

\$90.00: Hb: 978-0-521-11670-1 \$26.99: Pb: 978-0-521-13345-6: $296 \mathrm{pp}$.

Defeating Authoritarian Leaders in

Postcommunist Countries

VAlerie Bunce and SHARON WolchiK

Cambridge Studies in Contentious Politics

\$95.00: Hb: 978-1-107-00685-0 \$36.99: Pb: 978-0-521-18725-1: $384 \mathrm{pp}$.

Islamist Terrorism and

Democracy in the

Middle East

Katerina Dalacoura

\$85.00: Hb: 978-0-521-86518-0 \$26.99: Pb: 978-0-521-68379-1: $232 \mathrm{pp}$.
Economic Choices in a

Warming World

Christian de Perthuis

Translated by Michael Westlake

\$75.00: Hb: 978-1-107-00256-2

\$27.99: Pb: 978-0-521-17568-5: $260 \mathrm{pp}$.

Agenda Setting in the U.S. Senate

Costly Consideration and Majority Party Advantage

Chris Den Hartog and Nathan W. Monroe \$85.00: Hb: 978-1-107-00646-1. $240 \mathrm{pp}$.

Tocqueville: The Ancien Régime and the French

\section{Revolution}

Edited by JON ELSTER

Translated by

Arthur Goldhammer

Cambridge Texts in the History of Political Thought \$75.00: Hb: 978-0-521-88980-3 \$19.99: Pb: 978-0-521-71891-2: $320 \mathrm{pp}$.

\section{American Politicians}

Confront the Court

Opposition Politics and Changing Responses to Judicial Power

Stephen M. EnGeL

\$95.00: Hb: 978-0-521-19295-8 \$29.99: Pb: 978-0-521-15398-0: $384 \mathrm{pp}$.

\section{Criminologists}

on Terrorism and

Homeland Security

Edited by BRIAN FORST,

JACK R. GREene, and JAMES P. LYNCH Cambridge Studies in Criminology \$120.00: Hb: 978-0-521-89945-1: $494 \mathrm{pp}$.
The Politics of Prisoner Abuse The United States and Enemy Prisoners after 9/11

DAVid P. Forsythe

\$85.00: Hb: 978-1-107-00466-5 \$29.99: Pb: 978-0-521-18110-5: $336 \mathrm{pp}$.

\section{India Since 1980}

Sumit Ganguly and RAhul MukherJI The World Since 1980

\$85.00: Hb: 978-0-521-86093-2 \$27.99: Pb: 978-0-521-67804-9. $200 \mathrm{pp}$.

Symbols and Legitimacy in Soviet Politics

Graeme Gill

\$95.00: Hb: 978-1-107-00454-2 $362 \mathrm{pp}$.

Human Rights in the United States Beyond Exceptionalism Edited by Shareen Hertel and KATHRYN LIBAL

\$99.00: Hb: 978-1-107-00846-5 \$36.99: Pb: 978-1-107-40087-0: $392 \mathrm{pp}$.

The Invention of Market Freedom Eric MacGilvray \$90.00: Hb: 978-1-107-00136-7 \$26.99: Pb: 978-0-521-17189-2 $216 \mathrm{pp}$.

\section{Global Justice and}

Due Process

LARRY MAY

\$95.00: Hb: 978-0-521-76272-4 \$32.99: Pb: 978-0-521-15235-8: $260 \mathrm{pp}$.

Prices subject to change. 


\section{WHAT'S NEW IN POLITICAL SCIENCE?}
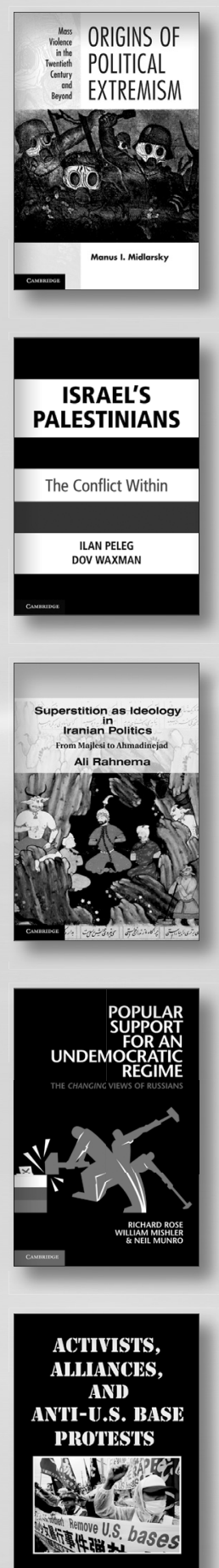

Domestic Law

Goes Global

Legal Traditions and

International Courts

Sara McLaughlin Mitchell and Emilia Justyna Powell

\$90.00: Hb: 978-1-107-00416-0:

$280 \mathrm{pp}$.

\section{Origins of}

Political Extremism

Mass Violence in the

Twentieth Century and Beyond

Manus I. Midlarsky

\$99.00: Hb: 978-0-521-87708-4

\$36.99: Pb: 978-0-521-70071-9: $442 \mathrm{pp}$.

Israel's Palestinians

The Conflict Within

Ilan Peleg

and Dov WAXMAN

\$85.00: Hb: 978-0-521-76683-8

\$27.99: Pb: 978-0-521-15702-5:

$280 \mathrm{pp}$.

War and the Crisis of Youth in Sierra Leone

Krijn Peters

The International African Library

\$90.00: Hb: 978-1-107-00419-1:

$296 \mathrm{pp}$.

\section{Superstition as}

Ideology in

Iranian Politics

From Majlesi to Ahmadinejad

Ali Rahnema

Cambridge Middle East Studies

\$95.00: Hb: 978-1-107-00518-1

\$28.99: Pb: 978-0-521-18221-8:

$320 \mathrm{pp}$.
The Politics of

Inequality in Russia

Thomas F. Remington

\$90.00: Hb: 978-1-107-09641-7

\$29.99: Pb: 978-1-107-42224-7:

$240 \mathrm{pp}$.

Popular Support

for an Undemocratic

Regime

The Changing Views

of Russians

RichaRd Rose,

William Mishler,

and Neil Munro

\$85.00: Hb: 978-1-107-00952-3

\$29.99: Pb: 978-0-521-22418-5:

$224 \mathrm{pp}$.

Ruling by Statute

How Uncertainty and Vote

Buying Shape Lawmaking

Sebastian M. Saiegh

\$90.00: Hb: 978-1-107-00565-5: $248 \mathrm{pp}$.

Gandhi in the West

The Mahatma and the

Rise of Radical Protest

\section{Sean Scalmer}

\$90.00: Hb: 978-0-521-76091-1 \$32.99: Pb: 978-0-521-13958-8: $254 \mathrm{pp}$.

\section{Building Global}

Democracy?

Civil Society and Accountable Global Governance

Edited by

JAN Aart Scholte

\$99.00: Hb: 978-0-521-19219-4 \$32.99: Pb: 978-0-521-14055-3: $424 \mathrm{pp}$.
The Legislative Legacy of Congressional

Campaigns

Tracy Sulkin

\$85.00: Hb: 978-0-521-51449-1 $\$ 25.99: \mathrm{Pb}: 978-0-521-73048-8$ : $232 \mathrm{pp}$.

\section{Religion and}

Modern Society

Citizenship, Secularisation and the State

BRYAN S. TURner

\$99.00: Hb: 978-0-521-85864-9 \$32.99: Pb: 978-0-521-67532-1: $372 \mathrm{pp}$.

\section{Young Thomas More} and the Arts of Liberty Gerard B. Wegemer \$85.00: Hb: 978-0-521-19653-6: $224 \mathrm{pp}$.

\section{Understanding}

Russian Politics

StePhen White

\$99.00: Hb: 978-0-521-86857-0 \$38.99: Pb: 978-0-521-68861-1: $488 \mathrm{pp}$.

\section{Oligarchy}

JefFrey A. Winters

\$95.00: Hb: 978-1-107-00528-0 \$29.99: Pb: 978-0-521-18298-0: $344 \mathrm{pp}$.

Activists, Alliances, and Anti-U.S. Base Protests AndRew Yeo

Cambridge Studies in Contentious Politics

\$90.00: Hb: 978-1-107-00247-0 \$27.99: Pb: 978-0-521-17556-2: $240 \mathrm{pp}$.

Prices subject to change. 


\title{
NEW IN POLITICAL SCIENCE
}

\section{Cambridge Handbook of Experimental Political Science}

\author{
Edited by \\ James N. Druckman, Donald P. Green, James H. Kuklinski, \\ and ARthur LUPIA \\ \$125.00: Hb: 978-0-521-19212-5: 604 pp. \\ \$48.00: $\mathrm{Pb}: 978-0-521-17455-8$
}

"This handbook is a monumental undertaking. It contains something of value for political scientists of every methodological and substantive stripe."

- Morris P. Fiorina, Stanford University

Laboratory experiments, survey experiments, and field experiments occupy a central and growing place in the discipline of political science. The Cambridge Handbook of Experimental Political Science is the first text to provide a comprehensive overview of how experimental research is transforming the field. Some chapters explain and define core concepts in experimental design and analysis. Other chapters provide an intellectual history of the experimental movement. Throughout the book, leading scholars review groundbreaking research and explain, in personal terms, the growing influence of experimental political science. This handbook provides a collection of insights that can be found nowhere else. Its topics are of interest not just to researchers who are conducting experiments today, but also to researchers who think that experiments can help them make new and important discoveries in political science and beyond.

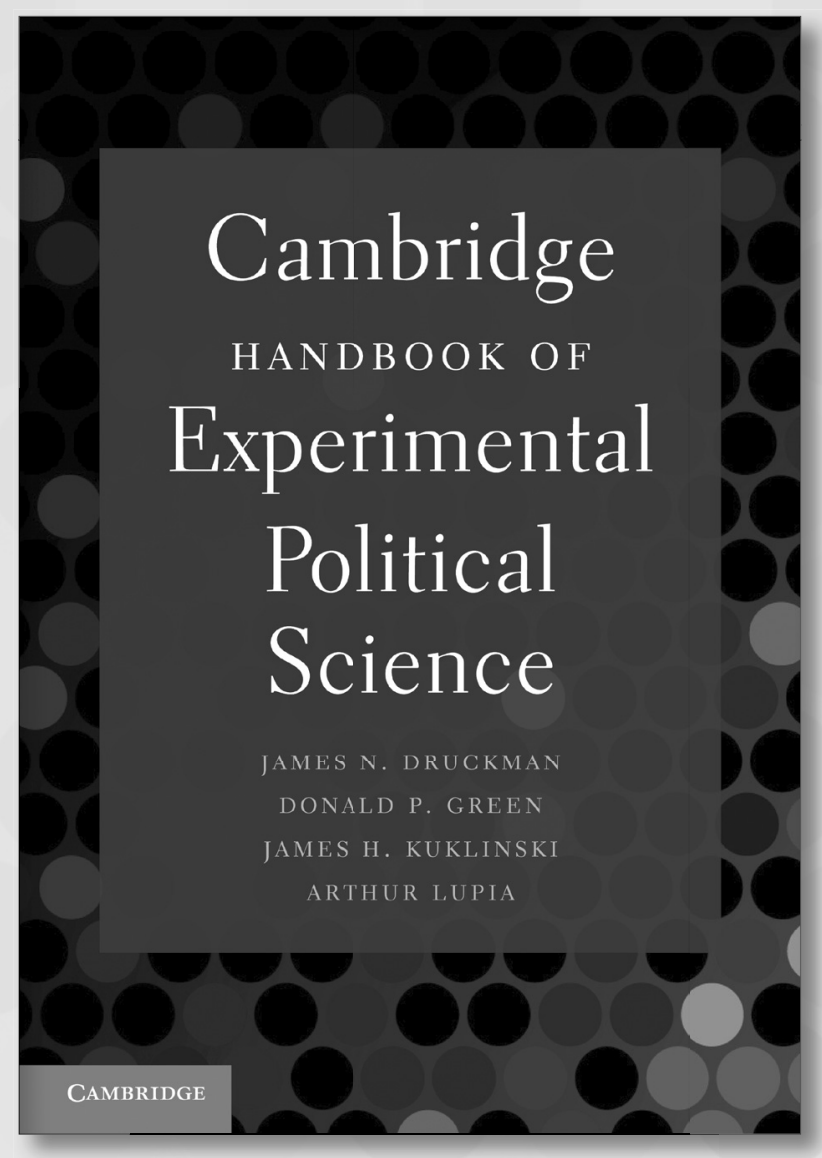

Prices subject to change. 


\section{NEW from KNOPF DOUBLEDAY}

\section{GREAT SOUL}

\section{Mahatma Gandhi and His Struggle with India by Joseph Lelyveld}

Pulitzer Prize-winner Joseph Lelyveld's highly original, stirring book is a vital, brilliant reconsideration of Gandhi's extraordinary struggles for social transformation and justice. Lelyveld deepens our sense of Gandhi's achievements and disappointments and a clear picture emerges of his fierce but, finally, unfulfilled hopes, and of his ever-evolving legacy, which more than six decades after his death still ensures his place as India's social conscience.

"[A] meditation on the interlinked puzzles of Mohandas 'Mahatma' Gandhi's strange personal disciplines, the communalistic passions of the two societies where Gandhi worked (South Africa and India), his improbable achievements against vast odds, and the ultimate failure of his ideals." —Foreign Affairs

Knopf I Cloth I 448 pages I \$28.95

\section{THE RIGHTS OF THE PEOPLE}

\section{How Our Search for Safety Invades Our Liberties}

\section{by David K. Shipler}

An impassioned, incisive look at the violations of civil liberties in the United States that have accelerated over the past decade — and their direct impact on our lives.

"[David] Shipler shows us, through carefully drawn and often moving accounts of real-life encounters between individuals and the state, the true cost of sacrificing liberty for security." —David Cole, author of No Equal Justice

"David Shipler has ... [taken] the guarantees in our Constitution and explored, on the ground, how they were actually being applied in the lives of Americans. The result is a wonderful book that shows how large a gap there is between constitutional promises and reality." - Anthony Lewis, author of Gideon's Trumpet

Knopf I Cloth I 400 pages I \$27.95

\section{MONEY AND POWER}

\section{How Goldman Sachs Came to Rule the World}

\section{by William D. Cohan}

A revelatory history of Goldman Sachs, the most dominant, controversial, and feared investment bank in the world. By reading thousands of pages of government documents and conducting over 100 interviews with clients, competitors, regulators, current and former Goldman employees (as well as the six living men who have run Goldman), William Cohan has constructed a vivid narrative that looks behind the veil of secrecy to reveal how Goldman has become so profitable, and so powerful.

Doubleday I Cloth I 672 pages I $\$ 30.50$

\section{TROUBLEMAKER}

A Memoir From the Front Lines of the Sixties by Bill Zimmerman

In his extraordinary memoir, Bill Zimmerman takes us into the hearts and minds of those who made the social revolution of the sixties. Frequently putting his life at risk for the greater social good, Zimmerman recounts his experiences on the front lines of the social revolution: registering black voters in deep in Mississippi; marching with Martin Luther King Jr. in Chicago; fighting the police at the 1968 Democratic convention; smuggling medicines to the front lines in North Vietnam. Zimmerman — who crossed paths with political organizers and activists like Abbie Hoffman, Daniel Ellsberg, César Chávez, Jane Fonda, and Tom Hayden — captures a groundbreaking zeitgeist that irrevocably changed the world as we knew it. Doubleday I Cloth I 464 pages I $\$ 28.95$

\section{AGE OF GREED}

\section{The Triumph of Finance and the Decline of America, 1970 to the Present \\ by Jeff Madrick}

A vividly told history of greed and its greatest practitioners in the last forty years, and how it gave rise to our current economic ills. As Jeff Madrick makes clear in a sweeping narrative the single-minded pursuit of huge personal wealth did not start in the 2000s but has been on the rise in the United States since the 1970 s, led by a few individuals who argued that self-interest guides society more effectively than community concerns. In telling the stories of the politicians, economists, and financiers - who declared a moral battle for freedom but gave rise to an age of greed-Madrick traces the lineage of some of our nation's most pressing economic problems.

Knopf I Cloth I 480 pages I $\$ 30.00$

\section{MAÑANA FOREVER?}

\section{Mexico and the Mexicans}

\section{by Jorge G. Castañeda}

In this shrewd and fascinating book, the renowned scholar and former foreign minister Jorge Castañeda sheds much light on the puzzling paradoxes of his native country. Castañeda examines the future possibilities for Mexico as it becomes more diverse in its regional identities, socially more homogenous, its character and culture the instruments of change rather than sources of stagnation, its political system more open and democratic. Mañana Forever? is a compelling portrait of a nation at a crossroads.

Knopf I Cloth I 320 pages I \$26.95 


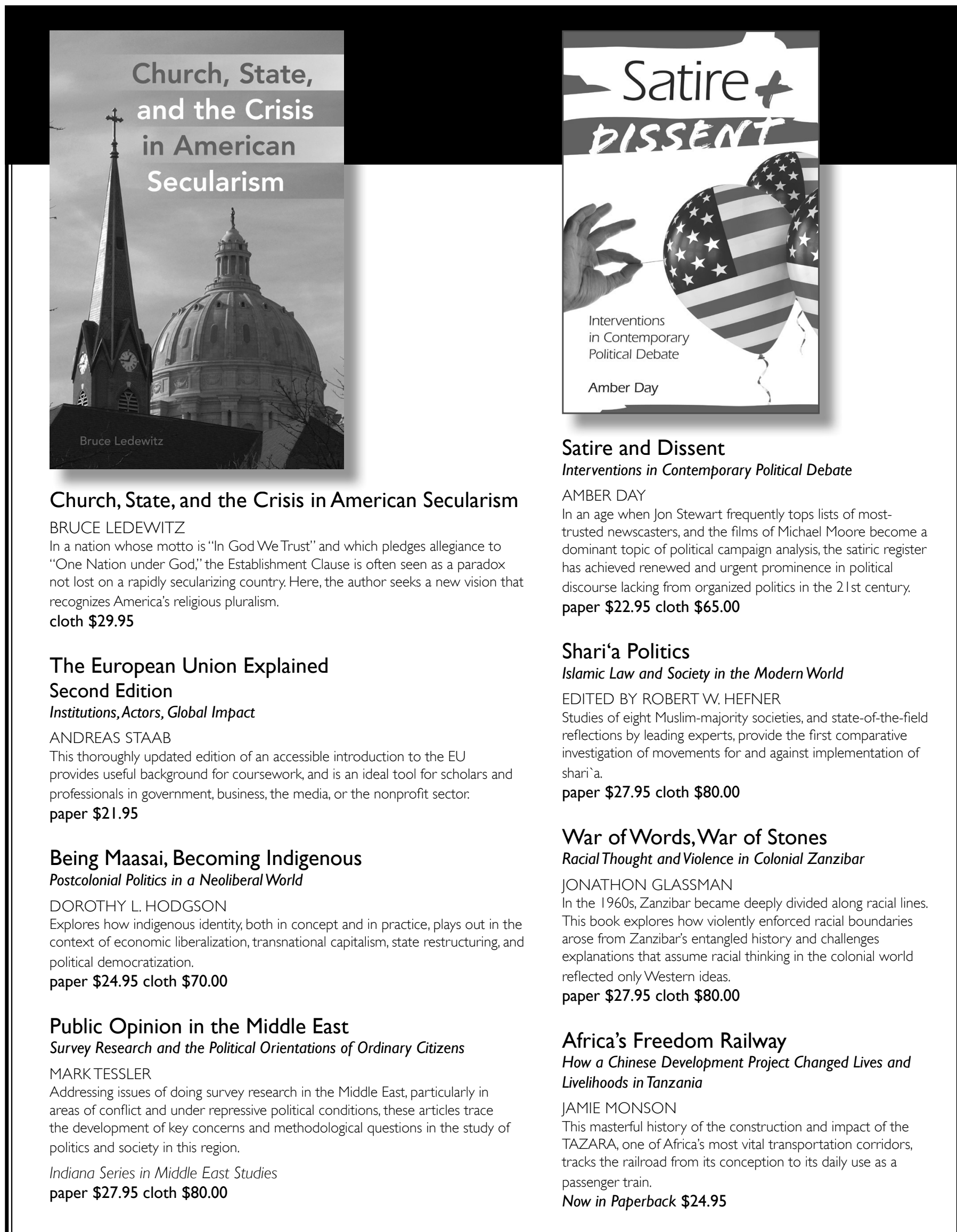

800-842-6796

iupress.indiana.edu 


\section{InNovative Perspectives on Politics}

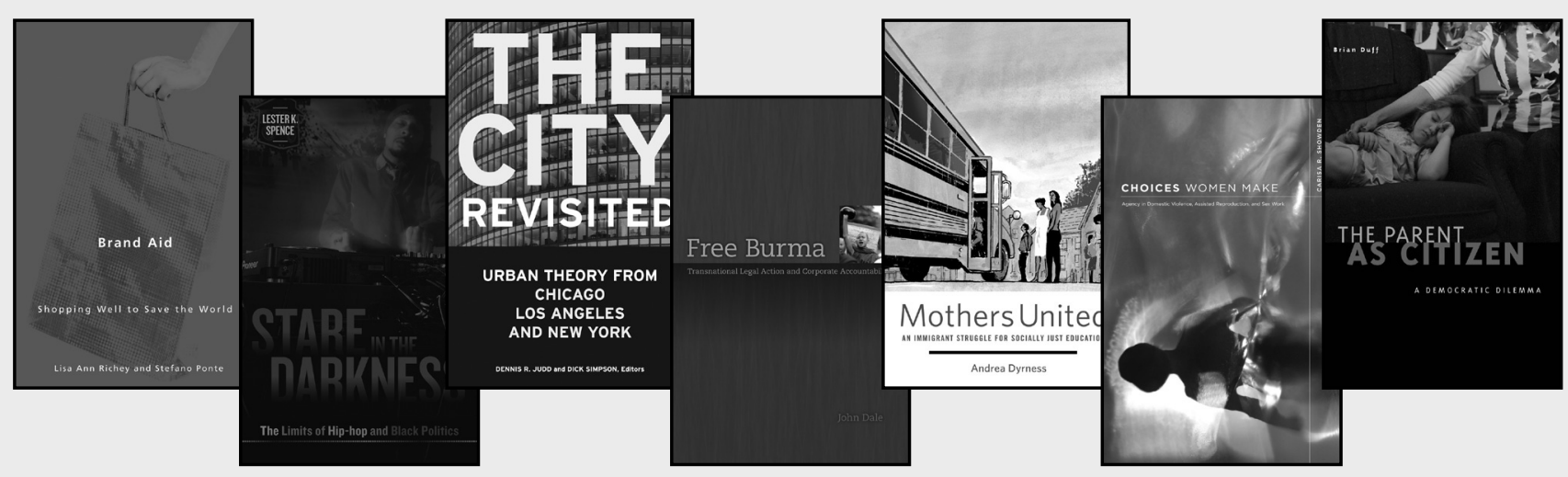

\section{Brand Aid}

Shopping Well to Save the World Lisa Ann Richey and Stefano Ponte

A stinging critique of "compassionate consumption" and celebrity-driven international aid and development such as Product RED.

$\$ 18.95$ paper $\bullet \$ 57.00$ cloth $\bullet 272$ page $\bullet$ A Quadrant Book

\section{Stare in the Darkness}

The Limits of Hip-hop and Black Politics

Lester K. Spence

Considers the prolific and prominent activities of hip-hop politics, revealing the political consequences of rap culture for black publics.

$\$ 22.50$ paper $\bullet \$ 67.50$ cloth $\bullet 240$ pages $\bullet$ Available July 2011

\section{The City, Revisited}

Urban Theory from Chicago, Los Angeles, and New York

\section{Dennis R. Judd and Dick Simpson, editors}

A spirited debate about whether the major theories of twentieth-century urban development are relevant for studying the twenty-first-century metropolis.

$\$ 25.00$ paper $\bullet \$ 75.00$ cloth $\bullet 392$ pages

\section{Fallout Shelter}

\section{Designing for Civil Defense in the Cold War} David Monteyne

Traces the partnership between architects and American civil defense officials during the Cold War.

$\$ 27.95$ paper $\bullet \$ 84.00$ cloth $\bullet 376$ pages

Architecture, Landscape, and American Culture Series

\section{The Parent as Citizen}

A Democratic Dilemma

Brian Duff

Reveals how efforts to make the experience of parenthood inform citizenship contribute to the most persistent problems in modern democracy and democratic theory.

$\$ 25.00$ paper $\bullet \$ 75.00$ cloth $\bullet 304$ pages

\section{Choices Women Make}

Agency in Domestic Violence, Assisted

Reproduction, and Sex Work

Carisa R. Showden

Investigates what exactly makes an agent and how that agency influences the ways women make inherently sensitive and difficult choices.

$\$ 25.00$ paper $\bullet \$ 75.00$ cloth $\bullet 304$ pages

\section{Mothers United}

An Immigrant Struggle for Socially Just Education Andrea Dyrness

Chronicles the experiences of five Latina immigrant mothers in Oakland, California as they become informed and engaged advocates for their children's education.

$\$ 22.95$ paper $\bullet \$ 69.00$ cloth $\bullet 264$ pages

\section{Free Burma}

Transnational Legal Action and Corporate Accountability John G. Dale

Demonstrates how social movements create and appropriate legal mechanisms for generating new transnational political opportunities.

$\$ 25.00$ paper $\bullet \$ 75.00$ cloth $\bullet 328$ pages $\bullet$ Available June 2011 


\section{New from Stanford University Press}
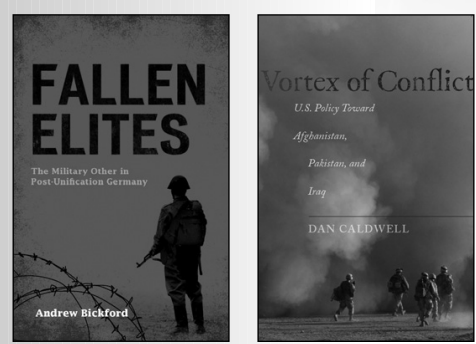

Fallen Elites

The Military Other in

Post-Unification Germany

ANDREW BICKFORD

"Makes a brilliant contribution to our thinking about militarism and the military's impact on social life. It has relevance well beyond the former East Germany and is a truly fascinating book."

—Lesley Gill, Vanderbilt University

\$22.95 paper $\$ 70.00$ cloth

\section{Vortex of Conflict}

U.S. Policy Toward

Afghanistan, Pakistan, and Iraq

DAN CALDWELL

"A holistic understanding of the wars in Iraq, Afghanistan, and Pakistan is long overdue. Dan Caldwell provides a reasoned analysis of the national security struggles we face as a nation, and what to do about them. Highly recommended." -John Nagl,

President of the Center for a New American Security and author of Learning to Eat Soup with a Knife \$25.95 paper $\$ 75.00$ cloth

\section{Beyond the Middle Kingdom Comparative Perspectives on China's Capitalist \\ Transformation}

Edited by SCOTT KENNEDY

"Revisit[s] salient issues of post-Mao Chinese development and masterfully compare them with those in carefully chosen reference societies on many analytical templates. Innovative and insightful.” -Tun-jen Cheng, College of William and Mary Contemporary Issues in Asia and the Pacific, East-West Center

$\$ 22.95$ paper $\$ 65.00$ cloth
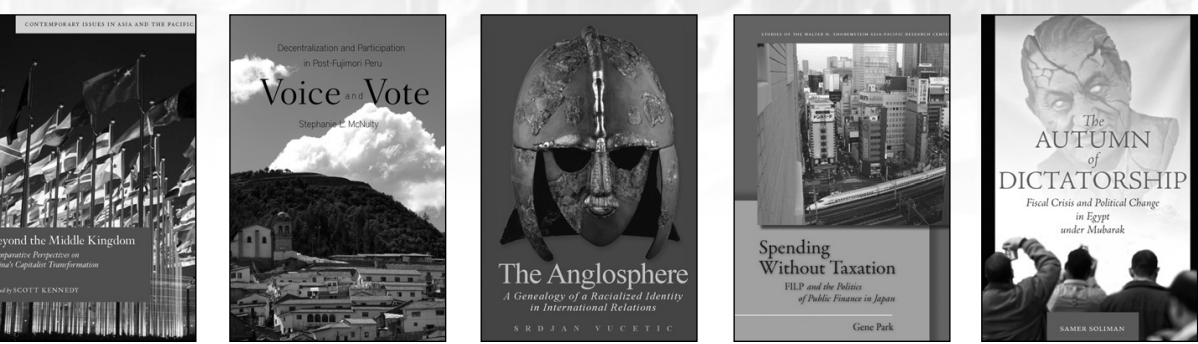

\section{Voice and Vote}

Decentralization and Participation in Post-Fujimori Peru

\section{STEPHANIE L. MCNULTY}

"Represents an impressive contribution to the literatures on decentralization and participatory democracy by showing what happens when participatory reforms are mandated from above rather than demanded from below." -Kent Eaton,

University of California, Santa Cruz $\$ 22.95$ paper $\$ 65.00$ cloth

\section{The Anglosphere}

A Genealogy of a Racialized Identity in International Relations

\section{SRDJAN VUCETIC}

"Analyzes the now officially forgotten racial-in-origin identification of AngloSaxon peoples and shows how it still matters in the close alignment of policies among the US, Great Britain, Canada, Australia, and New Zealand." -Robert Vitalis,

University of Pennsylvania $\$ 24.95$ paper $\$ 75.00$ cloth

The Autumn of Dictatorship Fiscal Crisis and Political Change in Egypt under Mubarak

\section{SAMER SOLIMAN}

"Soliman 'follows the money' to make convincing arguments about the character of the Egyptian state and regime, and about authoritarian politics more generally. A serious and refreshing interrogation."

-Samer Shehata, Georgetown University, author of Shop Floor Culture and Politics in Egypt

Stanford Studies in Middle Eastern and Islamic Societies and Cultures

$\$ 22.95$ paper $\$ 80.00$ cloth

\section{Innovation, Transformation, and War}

Counterinsurgency Operations in Anbar and Ninewa Provinces, Iraq, 2005-2007

\section{JAMES A. RUSSELL}

"This important book provides a vital corrective to the existing literature on military innovation which presents it as led from the top. For students, scholars, and practitioners of modern war, this is a 'must read."'

-Theo Farrell, King's College London $\$ 24.95$ paper $\$ 70.00$ cloth

\section{Becoming Asia}

Change and Continuity in Asian International Relations Since World War II

\section{ALICE LYMAN MILLER and RICHARD WICH}

"Tailor made for advanced courses on the history of Asian international relations, its readability and narrative structure also offer the general reader access to a historical perspective on a region that is transforming the world today." -Carla Freeman, Johns Hopkins School of Advanced International Studies $\$ 29.95$ paper $\$ 80.00$ cloth

\section{Spending Without Taxation}

FILP and the Politics of Public Finance in Japan

\section{GENE PARK}

" $[\mathrm{P}]$ rovides a compelling rationale for FILP's importance in Japan's postwar political economy."

-William W. Grimes, Boston University

Studies of the Walter H. Shorenstein Asia-Pacific Research Center

$\$ 55.00$ cloth

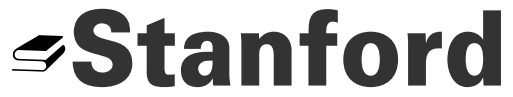

University Press 


\section{New Books from Yale}
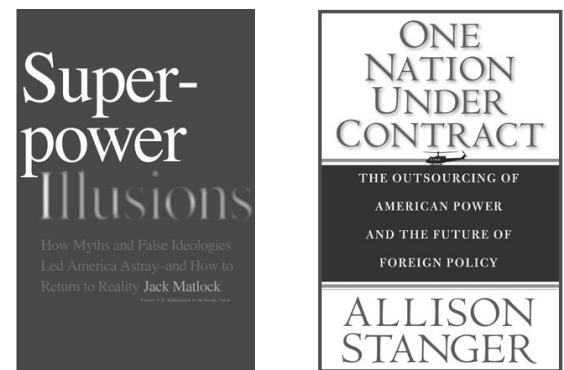

Now Available in Paperback

\section{Innovation and the State}

Political Choice and Strategies for

Growth in Israel, Taiwan, and Ireland

Dan Breznitz

\section{Superpower Illusions}

How Myths and False Ideologies Led America Astray--And How to Return to Reality

Jack F. Matlock, Jr.

\section{The Meaning of Property}

Freedom, Community, and the Legal Imagination

Jedediah Purdy

\section{Breaking the Logjam}

Environmental Protection That

Will Work

David Schoenbrod, Richard B.

Stewart, and Katrina M. Wyman; Illustrations by Deborah

Paulus-Jagric

\section{Toxic Bodies}

Hormone Disruptors and the

Legacy of DES

Nancy Langston

\section{Leo Strauss}

An Intellectual Biography

Daniel Tanguay

Palestine Betrayed Efraim Karsh

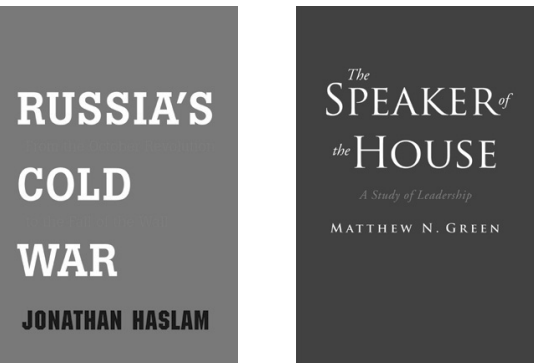

The Lomborg Deception

Setting the Record Straight About

Global Warming

Howard Friel; Foreword by

Thomas E. Lovejoy

\section{Grand Strategies}

Literature, Statecraft, and World Order

Charles Hill

\section{One Nation Under}

\section{Contract}

The Outsourcing of American Power and the Future of Foreign Policy

Allison Stanger

\section{Russia's Cold War}

From the October Revolution to the Fall of the Wall

Jonathan Haslam

\section{New in Cloth}

\section{Why Marx Was Right}

Terry Eagleton

Taking ten of the most common objections to Marxism-that it leads to political tyranny, that it reduces everything to the economic, that it is a form of historical determinism, and so on-Eagleton demonstrates what a travesty of Marx's own thought these assumptions are. Written with Eagleton's familiar wit, humor, and clarity, Why Marx Was Right is as urgent and timely as it is brave and candid.

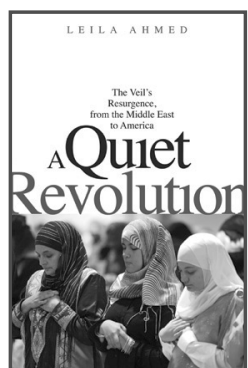

Terry Eagleton

why

marx

was

right

\section{The Disappearing Center} Engaged Citizens, Polarization, and American Democracy

Alan I. Abramowitz

\section{The Speaker of the House} A Study of Leadership

Matthew N. Green

\section{Selected Writings}

Jeremy Bentham

Edited by Stephen G. Engelmann

\section{Leviathan}

Or the Matter, Forme, \& Power

of a Common-Wealth

Ecclesiasticall and Civill

Thomas Hobbes

Edited and with an

introduction by Ian Shapiro

\section{A Quiet Revolution}

The Veil's Resurgence, from the Middle East to America

Leila Ahmed

This probing study of the veil's recent return-from one of the world's foremost authorities on Muslim women-reaches surprising conclusions about contemporary Islam's place in the West today. "A powerful and critically important analysis of the veil's modern history and reemergence in our time ... It is compelling reading for the many readers with questions about the veil and its meanings." —Diana Eck 


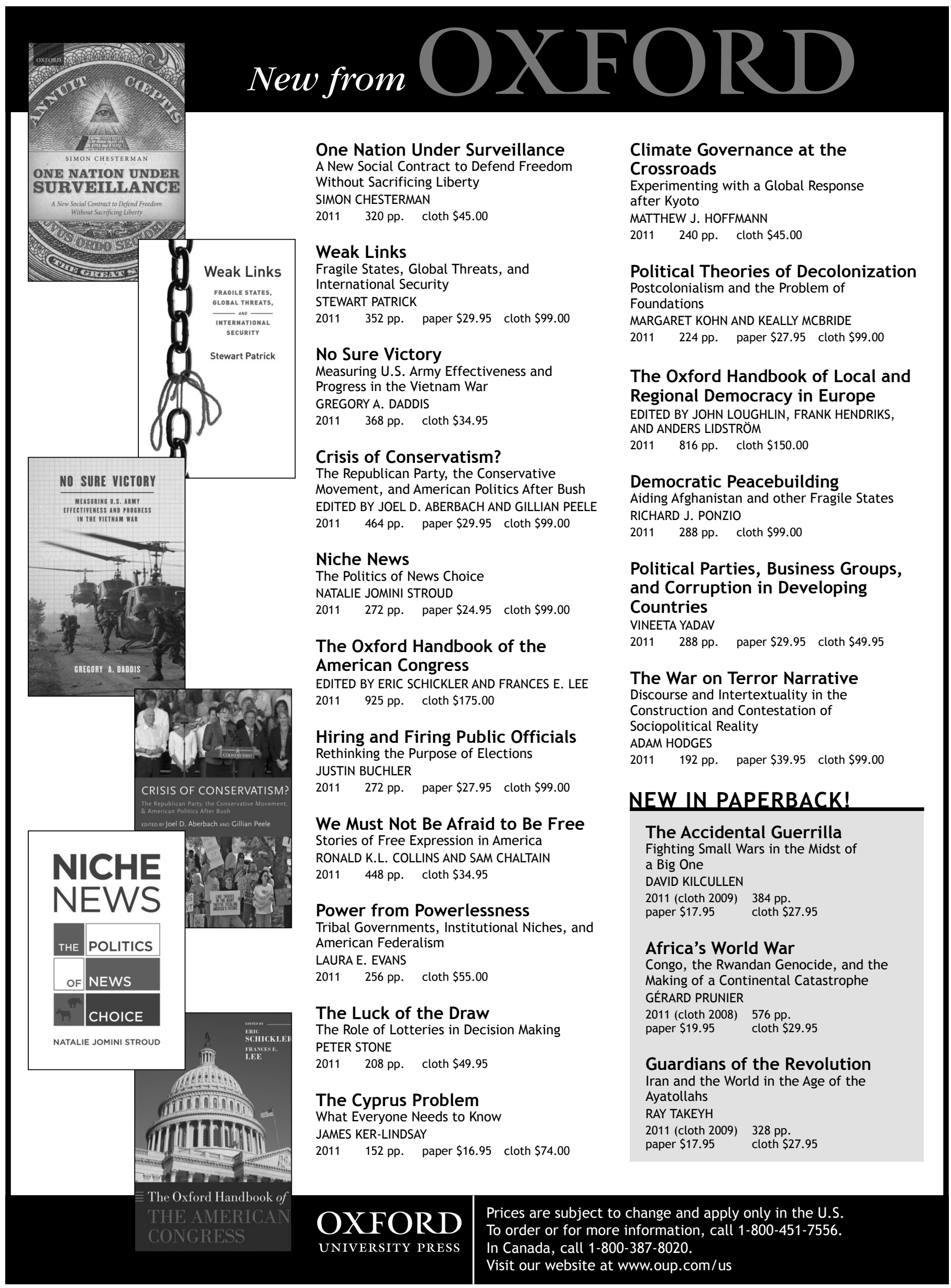




\section{INNOVATIVE PERSPECTIVES}
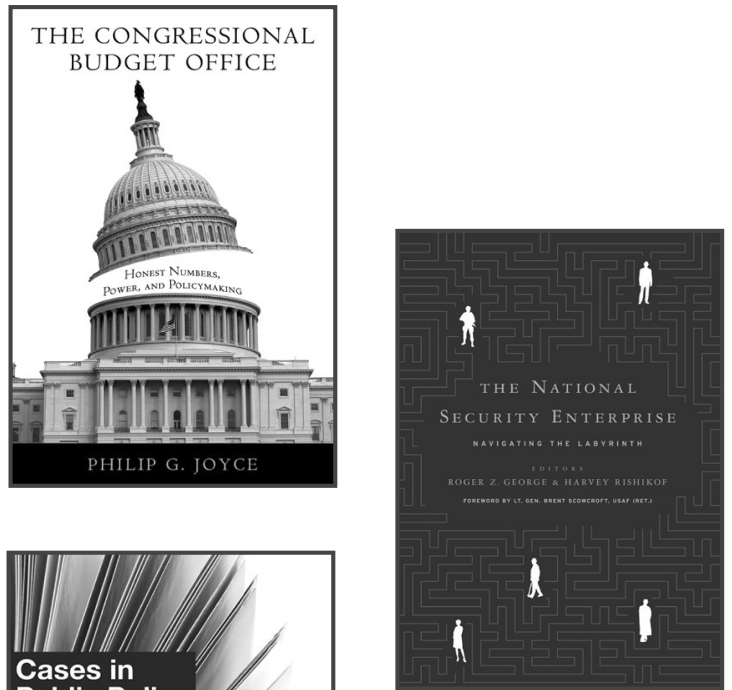

The Congressional Budget Office

Honest Numbers, Power, and Policymaking

Philip G. Joyce

978-1-58901-757-3, paperback, \$29.95

American Governance and Public Policy series

The National Security Enterprise

Navigating the Labyrinth

Roger Z. George and Harvey Rishikof, Editors

Foreword by Lt. Gen. Brent Scowcroft, USAF (Ret.)

978-1-58901-698-9, paperback, \$32.95
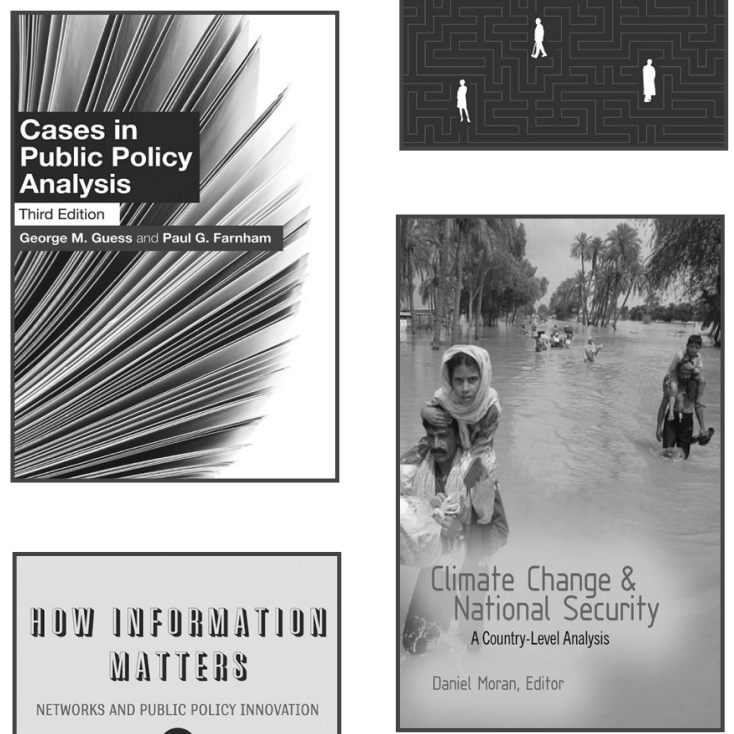

\section{Cases in Public Policy Analysis}

Third Edition

George M. Guess and Paul G. Farnham

978-1-58901-734-4, paperback, \$29.95

\section{Climate Change and National Security}

A Country-Level Analysis

Daniel Moran, Editor

978-1-58901-741-2, paperback, \$29.95

\section{How Information Matters}

Networks and Public Policy Innovation

Kathleen Hale

978-1-58901-700-9, paperback, \$29.95

Public Management and Change series

\section{Career Diplomacy}

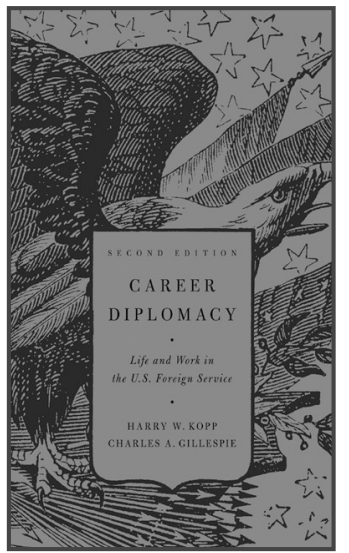

Life and Work in the U.S. Foreign Service

Second Edition

Harry W. Kopp and Charles A. Gillespie

978-1-58901-740-5, paperback, \$29.95

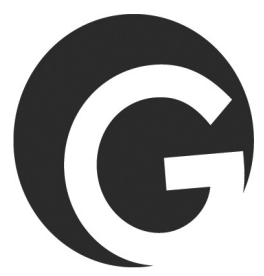

GEORGETOWN UNIVERSITY PRESS

800.537.5487 • www.press.georgetown.edu 


\section{NEW BOOK FROM THE

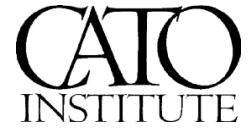

It has long been observed that global warming offers opportunities for a huge number of interests to exploit and that the eagerness to exploit the issue has led to a remarkable corruption of institutions-public, private, and academic. In a set of cogent and wellwritten contributions, Climate Coup documents what is happening intelligently and in depth., 9

- RICHARD S. LINDZEN

Massachusetts Institute of Technology

D espite convincing evidence that observed climate changes do not portend a calamitous future, global warming alarmism is invading nearly every aspect of our society. Leading climatologist Patrick Michaels and his team of first-rate experts show the pervasive influence global warming alarmism has on our lives-from national defense, law, trade, and politics to health, education, and international development.

HARDBACK: $\$ 24.95$ • EBOOK: $\$ 14.95$

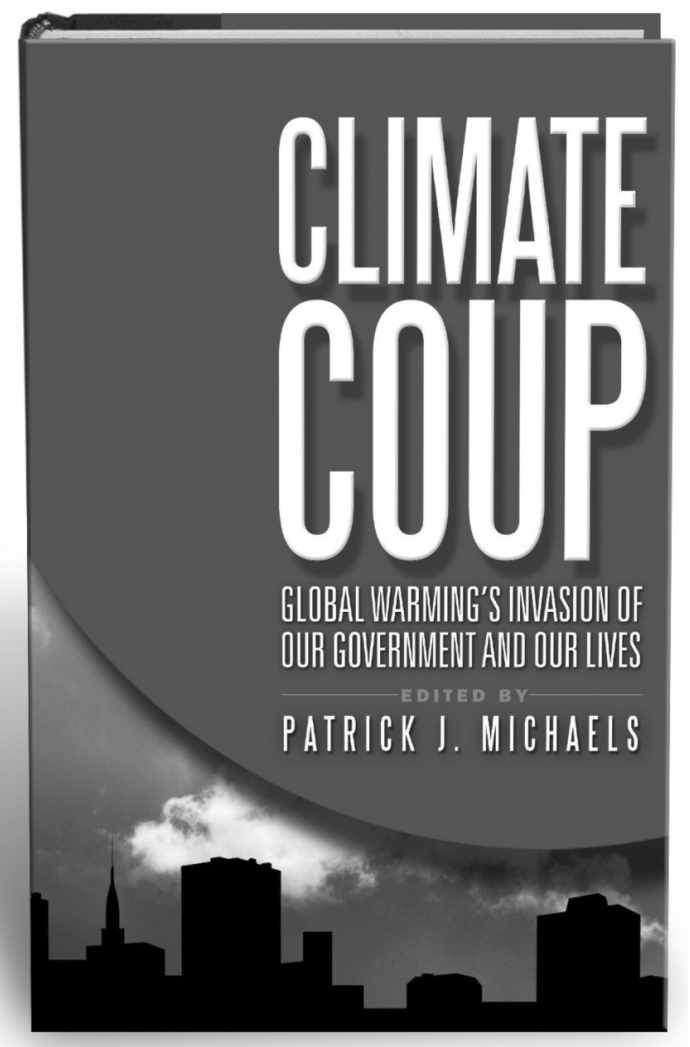

\section{Buy your copy at bookstores nationwide, call 800-767-1241, or visit Cato.org.}

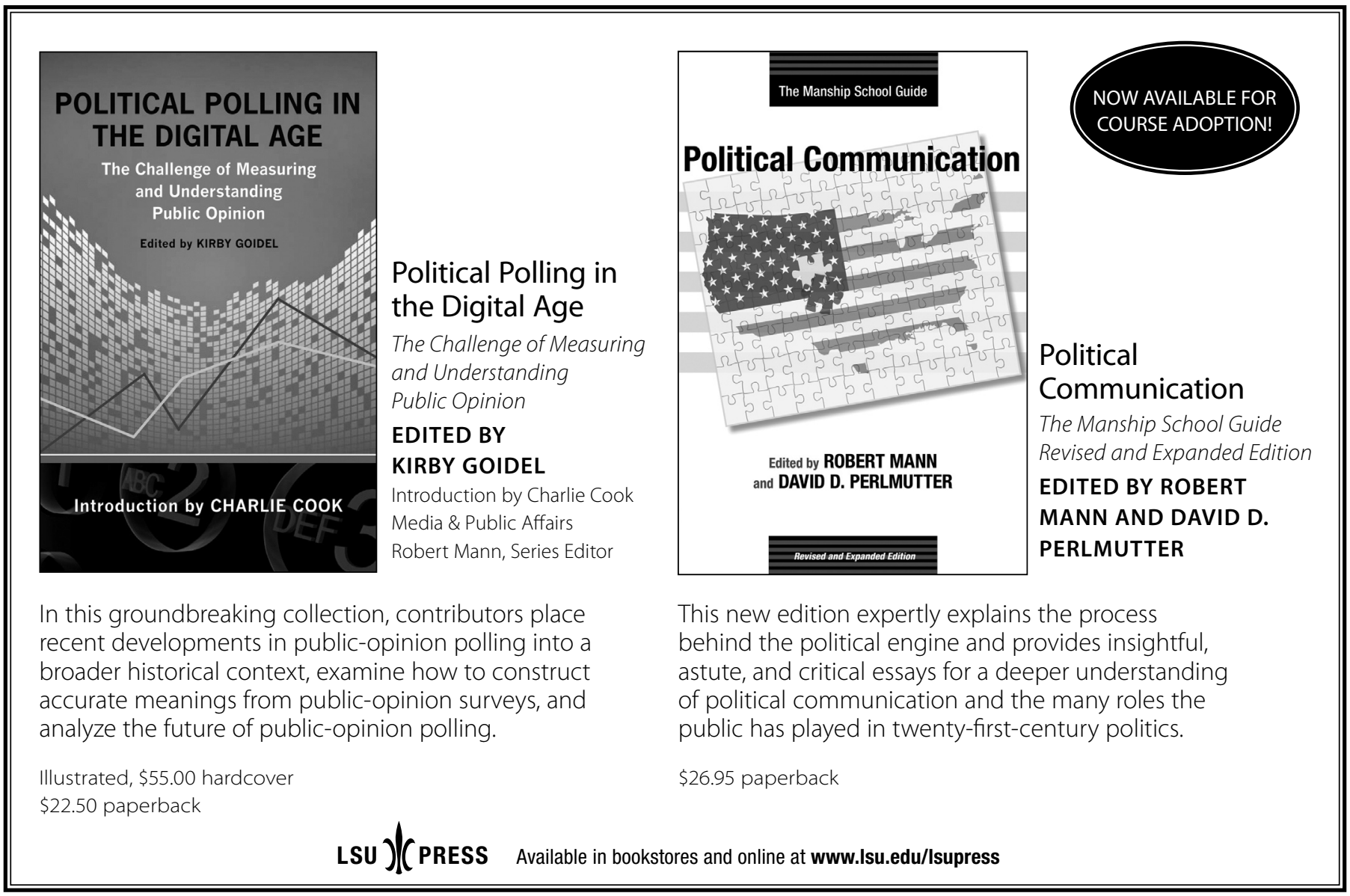




\section{NEW from PEN N PRESS}

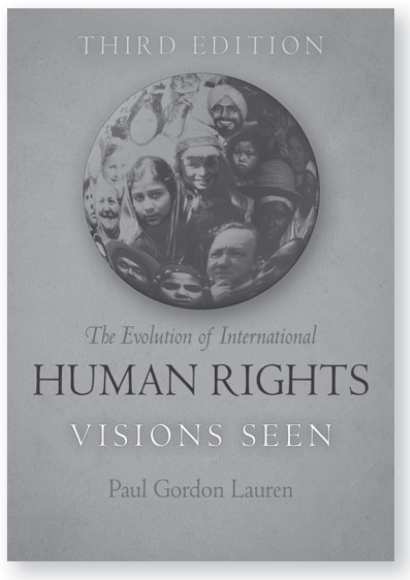

\section{FORGOTTEN GENOCIDES}

Oblivion, Denial, and Memory

Edited by René Lemarchand

Pennsylvania Studies in Human Rights

Jun 2011 | 224 pages | 4 illus. | Cloth | \$49.95

NOW IN A NEW EDITION

THE EVOLUTION OF INTERNATIONAL HUMAN RIGHTS

Visions Seen

Paul Gordon Lauren

Pennsylvania Studies in Human Rights

2011 | 480 pages | 16 illus. | Paper | \$34.95

\section{COMPETITIVE ELECTIONS AND THE AMERICAN VOTER}

Keena Lipsitz

American Governance: Politics, Policy, and Public Law Jun 2011 | 248 pages | 23 illus. | Cloth | \$49.95

\section{NEW IN PAPERBACK}

SOLDIERS, MARTYRS, TRAITORS, AND

EXILES

Political Conflict in Eritrea and the

Diaspora

Tricia Redeker Hepner

The Ethnography of Political Violence

2011 | 272 pages | Paper | \$22.50

NEW IN PAPERBACK

ENERGY POLITICS

Brenda Shaffer

2011 | 200 pages | 9 maps | Paper | \$19.95
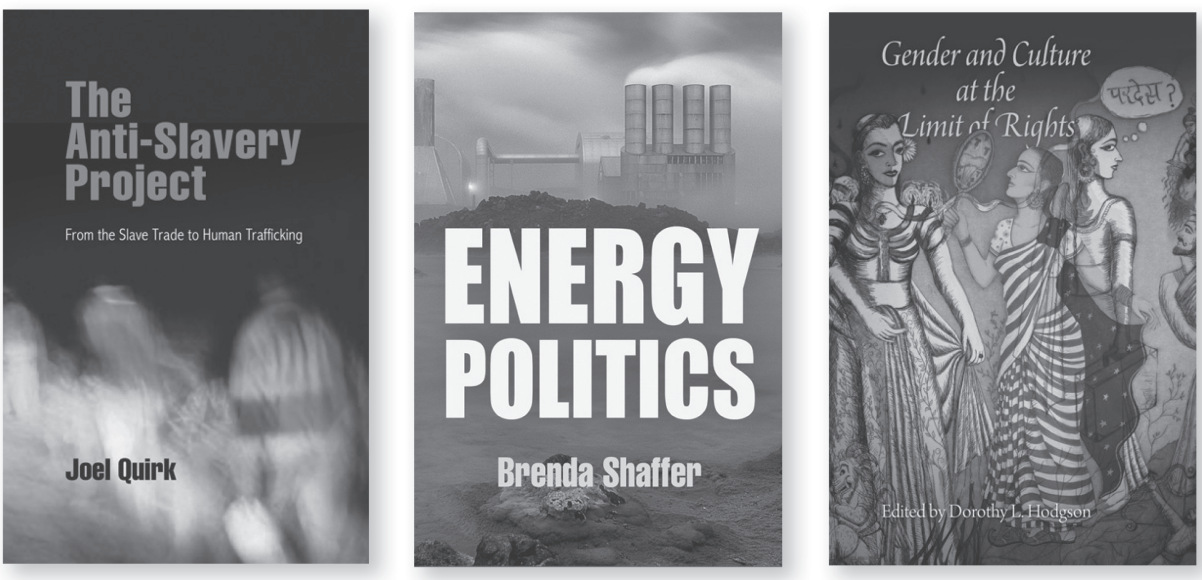

IMMIGRATION, ISLAM, AND THE POLITICS OF BELONGING IN FRANCE

A Comparative Framework Elaine R. Thomas

Pennsylvania Studies in Human Rights Jun 2011 | 320 pages | Cloth | \$65.00

\section{PALESTINIAN ETHNONATIONALISM IN ISRAEL \\ Oded Haklai \\ National and Ethnic Conflict in the 21st Century Jun 2011 | 264 pages | Cloth | \$59.95}

\section{LUSTRATION AND TRANSITIONAL JUSTICE}

Personnel Systems in the Czech Republic, Hungary, and Poland

Roman David

Pennsylvania Studies in Human Rights Jun 2011 | 328 pages | 11 illus. | Cloth | \$69.95

\section{THE ANTI-SLAVERY PROJECT}

From the Slave Trade to Human Trafficking Joel Quirk

Pennsylvania Studies in Human Rights Jun 2011 | 320 pages | Cloth | \$65.00

NEW IN PAPERBACK HUMAN RIGHTS IN LATIN AMERICA A Politics of Terror and Hope Sonia Cardenas

Pennsylvania Studies in Human Rights 2011264 pages | 20 illus. | Paper | \$24.95

\section{GENDER AND CULTURE AT THE LIMIT} OF RIGHTS

Edited by Dorothy L. Hodgson

Pennsylvania Studies in Human Rights Jun 2011 | 288 pages | 1 illus. | Cloth | \$47.50

\section{NEW IN PAPERBACK}

\section{GENDER STEREOTYPING}

Transnational Legal Perspectives

Rebecca J. Cook and Simone Cusack

Pennsylvania Studies in Human Rights

2011 | 288 pages | Paper | \$24.95

\section{NEW IN PAPERBACK}

\section{REPRODUCTIVE HEALTH AND HUMAN}

\section{RIGHTS}

The Way Forward

Edited by Laura Reichenbach and Mindy Jane Roseman

Pennsylvania Studies in Human Rights 2011 | 304 pages | 9 illus. | Paper | \$29.95

\section{SEXUAL VIOLENCE IN CONFLICT ZONES}

From the Ancient World to the Era of

Human Rights

Edited by Elizabeth D. Heineman

Pennsylvania Studies in Human Rights

2011 | 344 pages | Cloth | \$59.95

NEW IN PAPERBACK

REPARATIONS TO AFRICA

Rhoda E. Howard-Hassmann

With Anthony P. Lombardo

Pennsylvania Studies in Human Rights 2011 | 272 pages | Paper | \$24.95 


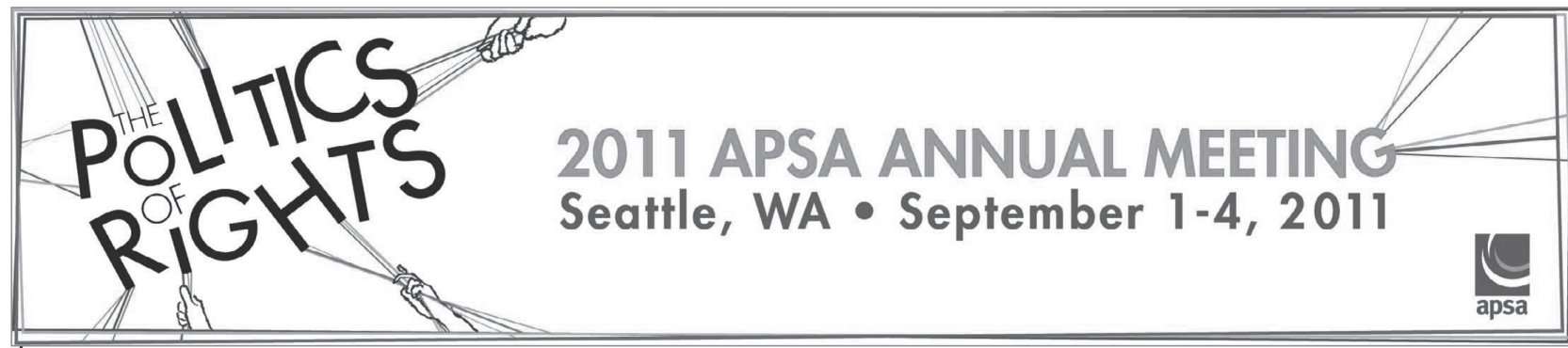

Join APSA in Seattle to address the latest scholarship in political science and to explore this year's theme "The Politics of Rights." APSA and the 2011 Program Chairs Frances Hagopian, University of Notre Dame, and Bonnie Honig, Northwestern University, encourage you to attend the 2011 APSA Annual Meeting in Seattle, Washington.

\section{JOIN THE CONVERSATION}

Nearly 7,000 political scientists will gather in Seattle to exchange ideas. Take advantage of more than 800 sessions per day.

\section{LOCATION, LOCATION}

Seattle boasts a unique combination of vibrant, urban attractions surrounded by incredible natural beauty. Whether it's shopping, dining and the arts you seek, or, waterways, national parks, and mountain peaks, it's all waiting for you there. Visitors to Seattle can also easily access everything from museums and open markets to a temperate rain forest and world-class wine region.

\section{LEARN MORE}

To learn more about the 2011 Annual Meeting, and to read the complete theme statement, visit www.apsanet.org/2011.

\section{See you in Seattle! www.apsanet.org/2011}

\begin{tabular}{|c|c|}
\hline \multicolumn{2}{|c|}{ Future APSA Conferences } \\
\hline \multicolumn{2}{|c|}{ APSA Annual Meeting \& Exhibition } \\
\hline August 30-September 2, 2012 & New Orleans, LA (Hilton/Marriott/Sheraton) \\
\hline August 29-September 1, 2013 & Chicago, IL (Hyatt/Sheraton) \\
\hline August 28-31, 2014 & Washington, D.C. (Omni/Hilton/Marriott) \\
\hline \multicolumn{2}{|c|}{ APSA Teaching \& Learning Conference } \\
\hline February 2012 & Washington, D.C. \\
\hline
\end{tabular}

\section{www.apsanet.org/conferences}

Cambridge Journals online

For further information about this journal please go to the journal website at: journals.cambridge.org/psr

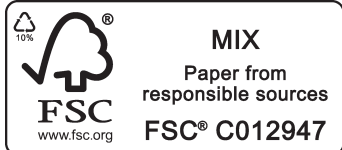

CAMBRIDGE UNIVERSITY PRESS 